\title{
Biocides in Sewage Sludge: Quantitative Determination in Some Swiss Wastewater Treatment Plants
}

\author{
C. Plagellat, T. Kupper, L. F. de Alencastro, D. Grandjean, J. Tarradellas \\ Laboratory of Environmental Chemistry and Ecotoxicology (CECOTOX), Faculty of \\ Architecture, Civil and Environmental Engineering, Swiss Federal Institute of \\ Technology (EPFL), CH-1015 Lausanne, Switzerland
}

Received: 22 March 2004/Accepted: 30 July 2004

Biocides are included in a wide range of products. In the present study, carbendazim (Car), Irgarol $1051^{\circledR}$ (Ir), octhilinone (Oc), permethrin (Per), tributyltin (TBT) and triphenyltin (TPT) with numerous industrial or domestic uses have been studied (Table 1). Data on consumption and uses of the these substances are difficult to obtain. In addition, there is a lack of data on these biocides sources and release processes into the environment. Lassen et al. (2001) have determined a consumption of active substances in biocidal products between 3,600 to 5,530 tonnes per year in Denmark for 1998/99. In Switzerland, such information is not available. Biocides released by private households and the industry may enter wastewater streams directly or they may end up in wastewater after aerial deposition on impervious surfaces and runoff into sewer systems. In wastewater treatment plants (WWTPs), lipophilic substances are mainly adsorbed onto sewage sludge. Sludge is therefore an appropriate matrix for the characterization of the release of numerous xenobiotic compounds (Oeberg et al. 2002; Chassot 1995). To describe the sources of pollutants and their distribution in the environment through the study of sewage sludge, additional informations such as the type of technology used for wastewater treatment, the collector system, socio-economic features and the type of industry present is required. Therefore, all samples of this study have been taken from WWTPs of a Swiss monitoring network with characterized observation sites (WWTP and the corresponding catchment). To date, only very little data on occurence of biocides in sludge is available. Thus, the present study aims to determine (i) the concentrations of biocides in sewage sludge, (ii) the specific loads of biocides in sewage sludge sampled in different types of monitoring sites and (iii) their main sources.

\section{MATERIALS AND METHODS}

The monitoring network comprises three types of sites described by Kupper et al. (2004). Sites of type A include a separate sewer system and a rural catchment without industrial activities apart from a few craft industries. Sites B exhibit the same characteristics but the catchment has a combined sewer system and more numerous craft industries. Sites of type $C$ have a combined sewer system and an urban catchment with craft industries and some types of industrial activities. In January and May 2001, samples of sewage sludge were collected in the 12 different WWTPs of this monitoring network as described by Kupper et al. (2004). 
Table 1. Name, $\mathrm{N}^{\circ} \mathrm{CAS}$ and applications of the measured biocides

\begin{tabular}{|c|c|}
\hline $\begin{array}{l}\text { Carbendazim (10605-21-7, benzimi- } \\
\text { dazole, fungicide) preservative for ma- } \\
\text { sonry, fibrous or polymerised material, } \\
\text { coating, paint, wood and non-alimentary } \\
\text { products, disinfectant, agriculture }\end{array}$ & $\begin{array}{l}\text { Irgarol } 10511^{\circledR} \quad(28159-98-0, \text { triazine, } \\
\text { algicide) emulsion paint and antifouling } \\
\text { paint }\end{array}$ \\
\hline $\begin{array}{l}\text { Octhilinone (26530-20-1, isothazolo- } \\
\text { ne, fungicide) preservative of non-ali- } \\
\text { mentary products, paint, leather and } \\
\text { leather products, preservation of cooling } \\
\text { water, heating and processing systems, } \\
\text { pest control }\end{array}$ & $\begin{array}{l}\text { Permethrin (52645-53-1, pyrethroid, } \\
\text { insecticide) repellent/insectide for clo- } \\
\text { thing, household insect foggers and } \\
\text { sprays, flea dips and sprays for cats and } \\
\text { dogs, ornamental garden and turf pro- } \\
\text { ducts, termite treatment, lice shampoos } \\
\text { and body lotion for scabies control, } \\
\text { wood preservative, agriculture }\end{array}$ \\
\hline $\begin{array}{l}\text { TBT (688-73-3, organotin, fungicide, } \\
\text { algicide) preservative for wood, timber } \\
\text { and material (stone, leather, paper, texti- } \\
\text { le), antifouling paints, disinfection, coo- } \\
\text { ling systems, dispersion paints, PVC }\end{array}$ & $\begin{array}{l}\text { TPT (668-34-8, or } \\
\text { moth proofing of tex } \\
\text { paints and in agricult }\end{array}$ \\
\hline
\end{tabular}

Permethrin (95.5\%), octhilinone (96.5\%), TBT choride $(96.5 \%)$ were obtained from Dr. Ehrenstorfer, Augsburg, Germany. TPT chloride (98.0\%), NaCl, $\mathrm{Na}_{2} \mathrm{SO}_{4}$, $\mathrm{H}_{2} \mathrm{SO}_{4}, \mathrm{NaOH}, \mathrm{K}_{2} \mathrm{CO}_{3}$ and silica gel 40 (activated $12 \mathrm{~h}$ at $350{ }^{\circ} \mathrm{C}$ ) were supplied from Merck, Dietikon, Switzerland. Carbendazim (99.8 \%) and Irgarol $1051^{\circledR}$ (97.6\%) were supplied by Promochem, Wesel, Germany and by Ciba Speciality Chemicals, Basel, Switzerland, respectively. All solvents were super-purity solvents from Romil, Cambridge, England or analytical-grade from Merck, Dietikon, Switzerland. Florisil (100-200 mesh, activated $2 \mathrm{~h}$ at $\left.650^{\circ} \mathrm{C}\right)$ was purchased from Fluka, Buchs, Switzerland. Pentafluorobenzyl bromide (PFB-Br) was used as derivatization agents from Aldrich, Buchs, Switzerland. Three-ml SiOH cartridges containing $500 \mathrm{mg}$ of unmodified silica were from Macherey-Nagel Chromabond, Düren, Germany, while aminopropyl-bonded silica was from Supelco, Buchs, Switzerland. Basic alumina $\left(50-200 \mu \mathrm{m}\right.$, activated $16 \mathrm{~h}$ at $\left.350^{\circ} \mathrm{C}\right)$ by Alltech, Deerfield, USA. For the purification on Gel Permeation Chromatography, a 600/20-mm glasscolumn fitted with a $5 \mathrm{ml}$ sample loop and packed with $100 \mathrm{~g}$ of Bio-Beads SX3 (BioRad, Hercules, USA) has been used. One cm I.D. glass columns conditionned with hexane were used for the clean-up. Due to the different chemical characteristics of the studied biocides, three different methods were required. Reagent blanks were prepared and analysed prior to applying any of the methods. The analytical method for organotin compounds has been described by Becker van Slooten et al. (1994).

For Irgarol $1051{ }^{\circledR}$ and octhilinone, $60 \mathrm{~g}$ of bulk sludge mixed with $5 \mathrm{~g}$ of $\mathrm{NaCl}$ were shaked with $30 \mathrm{ml}$ of pentane:dichloromethane $(4: 1, \mathrm{v}: \mathrm{v})$ for $30 \mathrm{~min}$. The supernatant was dried over $\mathrm{Na}_{2} \mathrm{SO}_{4}$ and extraction was repeated twice. This extract, reduced to $1 \mathrm{ml}$ in isooctane, was cleaned-up on a column prepared with $4 \mathrm{~g}$ of florisil and $\mathrm{Na}_{2} \mathrm{SO}_{4}$. Four fractions were eluted: $20 \mathrm{ml}$ of hexane discarded, $30 \mathrm{ml}$ of hexane:acetone $(9: 1, \mathrm{v}: \mathrm{v})$ with Irgarol $1051^{\circledR}, 10 \mathrm{ml}$ of dichloromethane:acetone $(7: 3, \mathrm{v}: \mathrm{v})$ discarded and $20 \mathrm{ml}$ of dichloromethane:acetone $(7: 3, \mathrm{v}: \mathrm{v})$ containing octhilinone. The second fraction was concentrated and cleaned-up on a 8-g basic 
alumina column. Irgarol $1051^{\circledR}$ was eluted with $30 \mathrm{ml}$ of hexane/acetone (9:1, v:v) after washing with $20 \mathrm{ml}$ hexane and $30 \mathrm{ml}$ hexane:acetone $(9: 1, \mathrm{v}: \mathrm{v})$. Octhilinone's fraction was transfered on a glass cartridge with $1 \mathrm{~g}$ of aminopropyl-bonded silica sorbent. The cartridge was rinsed with $4 \mathrm{ml}$ of hexane/acetone $(90: 10, \mathrm{v}: \mathrm{v})$ and octhilinone was eluted with $6 \mathrm{ml}$ of hexane/acetone $(4: 1)$. The extracts were re-dissolved in isooctane for analysis.

For carbendazim and permetrin, $70 \mathrm{~g}$ of sample (with $5 \mathrm{ml}$ of phosphate buffer and $4 \mathrm{~g}$ of $\mathrm{NaCl})$ was shaked with $25 \mathrm{ml}$ of hexane:ethyl acetate $(1: 1, \mathrm{v}: \mathrm{v})$ for $30 \mathrm{~min}$. Extraction was repeated twice with $15 \mathrm{ml}$ of solvent. Hexane was evaporated to adjust the volume at $30 \mathrm{ml}$ with ethyl acetate. The extract was washed with $10 \mathrm{ml}$ of water at $\mathrm{pH}$ adjusted to $12-13$ with $\mathrm{NaOH} 5 \mathrm{~N}, 10 \mathrm{ml}$ of MilliQ water and then twice with $10 \mathrm{ml}$ of $\mathrm{H}_{2} \mathrm{SO}_{4}(0.025 \mathrm{M})$. The acidic phase was washed with $15 \mathrm{ml}$ of ethyl acetate. The two organic phases (containing permethrin) were combined for purification on GPC. The two acidic phases (containing carbendazim) were combined, adjusted to basic $\mathrm{pH}$ with $\mathrm{NaOH}(5 \mathrm{~N})$ and extracted three times with $10 \mathrm{ml}$ of ethyl acetate. This phase containing carbendazim was re-dissolved in $1 \mathrm{ml}$ of acetonitrile for derivatization with $100 \mu \mathrm{l}$ of $\mathrm{K}_{2} \mathrm{CO}_{3} 25 \%$ (w/w) in MilliQ water and 100 $\mu 1$ of $\mathrm{PFB}-\mathrm{Br} 15 \%(\mathrm{w} / \mathrm{w})$ in acetonitrile for $3 \mathrm{~h}$ at $60^{\circ} \mathrm{C}$. Toluene was added to evaporate acetonitrile and then percolated on a $\mathrm{SiOH}$ cartridge conditioned with hexane. To eliminate PFB-Br the cartridge was washed with $8 \mathrm{ml}$ of toluene:hexane (3:17, v:v). Carbendazime was recovered with $4 \mathrm{ml}$ of acetone:hexane (1:4, v:v) after descarding the two first $\mathrm{ml}$. The volume of the organic phase containing permethrin was reduced to $1 \mathrm{ml}$ and $5 \mathrm{ml}$ of hexane:dichloromethane $(1: 1, \mathrm{v}: \mathrm{v})$ were added before injecting into the GPC. The analytes were collected in the fraction between $175 \mathrm{ml}$ and $225 \mathrm{ml}$ of hexane:dichloromethane $(1: 1, \mathrm{v}: \mathrm{v})$ at a $5 \mathrm{ml} / \mathrm{min}$ flow. The extract was purified on a column prepared with $5 \mathrm{~g}$ of silica gel, $4 \mathrm{~g}$ of florisil (5\% of water), $4 \mathrm{~g}$ of $\mathrm{Na}_{2} \mathrm{SO}_{4}$. Permethrin was recovered with $30 \mathrm{ml}$ of acetone:hexane $(1: 4, \mathrm{v}: \mathrm{v})$ after discarding the first $15 \mathrm{ml}$. Sulfur was eliminated on $1 \mathrm{~g}$ of copper activated with $3 \mathrm{ml}$ of nitric acide $(7 \mathrm{~N})$, rinsed with MilliQ water until neutral $\mathrm{pH}$, conditioned with $3 \mathrm{ml}$ of acetone and $3 \mathrm{ml}$ of hexane.

GC/ECD was used for the quantitative analyses of permethrin (HP 6890 Series) and GC/MS (Varian $1200 \mathrm{~L}$ ) for carbendazim (m/z:181/292/492), Irgarol $1051^{\circledR}$ (m/z: 82/196/238/253) and octhilinone (m/z: 101/114/213). TBT and TPT were analysed on a GC/PFPD- mode P (Varian star $3400 \mathrm{CX}$ ). Table 2 shows the operating conditions. All concentrations were determined using external standards and corrected for the recovery. Organotin results refer to the TBT and TPT as the ion $\left(\mathrm{Bu}_{3} \mathrm{Sn}^{+}\right.$and $\left.\mathrm{Phe}_{3} \mathrm{Sn}^{+}\right)$.

In order to test the validity of the methods, a routine sample recovery measurement have be made as described by Hess et al. (1995) and Wegener et al. (1997). Samples of sludge were spiked with the biocides at four concentrations: $50 \%, 100 \%, 150 \%$ and $200 \%$ of their initial concentration (carbendazim, permethrin, TBT, TPT) or at about 5, 10, 15 and 20 times the detection limit for Irgarol $1051^{\circledR}$ and octhilinone (not found in the sample). These samples were taken through the procedures. The slope of the regression of the experimental quantities expressed as a function of the theoretical quantities gives the recovery. The standard deviation of the slope corresponds to the standard deviation of the recovery. The limit of detection (signal-tonoise ratio of 3) of the whole analytical procedure was calculated with a spiked sam- 
Table 2. Conditions of the chromatographic analysis for the detection of the biocides in sewage sludge

\begin{tabular}{|c|c|c|}
\hline & Injection system & Column/Program \\
\hline Car & $\begin{array}{l}\text { Varian } 1079 \mathrm{PTV} \\
85^{\circ} \mathrm{C}(0.2 \mathrm{~min})\end{array}$ & $\begin{array}{l}\mathrm{DB}-5-\phi 0.25 \times 60 \mathrm{~m}, 0.25 \mu \mathrm{m} \\
80^{\circ} \mathrm{C}(0.5 \mathrm{~min})-50^{\circ} \mathrm{C} / \mathrm{min} \text { to } 150^{\circ} \mathrm{C}(1 \mathrm{~min}) \\
2.5^{\circ} \mathrm{C} / \mathrm{min} \text { to } 240^{\circ} \mathrm{C}(20 \mathrm{~min})\end{array}$ \\
\hline Ir & $100^{\circ} \mathrm{C} / \mathrm{min}$ to $250^{\circ} \mathrm{C}$ & $\begin{array}{l}\mathrm{DB}-5-\phi 0.25 \times 60 \mathrm{~m}, 0.25 \mu \mathrm{m} \\
80^{\circ} \mathrm{C}(1 \mathrm{~min})-8^{\circ} \mathrm{C} / \mathrm{min} \text { to } 190^{\circ} \mathrm{C}(30 \mathrm{~min})\end{array}$ \\
\hline Oc & $\begin{array}{l}\text { Varian } 1079 \mathrm{PTV} \\
250^{\circ} \mathrm{C}\end{array}$ & $\begin{array}{l}\mathrm{DB}-5-\phi 0.25 \times 60 \mathrm{~m}, 0.25 \mu \mathrm{m} \\
80^{\circ} \mathrm{C}(1 \mathrm{~min})-40^{\circ} \mathrm{C} / \mathrm{min} \text { to } 150^{\circ} \mathrm{C}-3^{\circ} \mathrm{C} / \mathrm{min} \text { to } 220^{\circ} \mathrm{C}\end{array}$ \\
\hline Per & On column & $\begin{array}{l}\text { DB-5 - } \phi 0.25 \times 60 \mathrm{~m}, 0.25 \mu \mathrm{m} \\
80^{\circ} \mathrm{C}(0.5 \mathrm{~min})-50^{\circ} \mathrm{C} / \mathrm{min} \text { to } 150^{\circ} \mathrm{C} \\
150^{\circ} \mathrm{C}(1 \mathrm{~min})-2.5^{\circ} \mathrm{C} / \mathrm{min} \text { to } 285^{\circ} \mathrm{C}\end{array}$ \\
\hline $\begin{array}{l}\text { TBT } \\
\text { TPT }\end{array}$ & $\begin{array}{l}\text { Splitless } \\
250^{\circ} \mathrm{C}\end{array}$ & $\begin{array}{l}\mathrm{HP}-1-\phi 0.20 \times 25 \mathrm{~m}, 0.33 \mu \mathrm{m} \\
40^{\circ} \mathrm{C}(1 \mathrm{~min})-10^{\circ} \mathrm{C} / \mathrm{min} \text { to } 280^{\circ} \mathrm{C}(15 \mathrm{~min})\end{array}$ \\
\hline
\end{tabular}

ple and was adjusted to the recovery rate. Suitable recoveries were obtained: carbendazim, $85.4 \% \pm 9.6$; Irgarol $1051^{\circledR}, 95.0 \% \pm 10.1$; octhilinone $76.9 \% \pm 1.4$, cispermethrin, $78.5 \% \pm 9.7$; trans-permethrin, $82.3 \% \pm 9.7$; TBT, $106.5 \% \pm 18.6$ and TPT, $91.4 \% \pm 8.4$. The limits of detection were (ng $/ \mathrm{kg}$ of bulk sludge): carbendazim, 12.5; Irgarol $1051^{\circledR}, 65.8$; octhilinone, 160; cis-permethrin, 9.1; trans-permethrin, 8.7; TBT, 323 and TPT, 201. A sample has been analysed three times: the RSD was $4 \%, 18 \%$ and $19 \%$ for carbendazim, cis-permethrin and trans-permethrin. As suitable recoveries and repetability have been found with these methods, single analysis has been carried out for each sample.

\section{RESULTS AND DISCUSSION}

The concentrations of both sampling periods are shown in Table 3. All substances, except for octhilinone that was not detected, were found at a level of $\mu \mathrm{g} / \mathrm{kg}$ dry weight (d.w.) Although present in all samples, measured concentrations of carbendazim were low (mean of $6.8 \mu \mathrm{g} / \mathrm{kg} \mathrm{d.w.).} \mathrm{Irgarol} 1051^{\circledR}$ was found in 7 out of 24 samples at low concentrations only (mean of $2.9 \mu \mathrm{g} / \mathrm{kg} \mathrm{d} . \mathrm{w}$.). It is used as an algicide in emulsion paints for walls and its presence in sewage sludge may be the result of leaching during rain events or misuse during handling of equipment containing Irgarol $1051^{\circledR}$.

Both permethrin isomers were detected in all sludge samples (mean of $55.3 \mu \mathrm{g} / \mathrm{kg}$ d.w. for cis-isomer and $42.8 \mu \mathrm{g} / \mathrm{kg} \mathrm{d}$.w. for trans-isomer). In most cases the concentration of the cis-isomer was higer than the trans-isomer's. This cis/trans ratio is comparable to ratios observed in other environmental matrices: 1.6 in water and 1.5 in moss (Hancock et al. 1997). This might be explained by a lower degradability of the cis isomer. The study of Sharom and Salomon (1981) on degradation of permethrin in water and flooded sediment has shown that the biological degradability and chemical hydrolysis of the cis-isomer is lower. Commercial formulas and applications have distinct cis/trans ratios; as the cis/trans ratio depends on the rates of degradation, it cannot be used as a marker to identify the sources of permethrin in sewage sludge. The concentrations of permethrin of this study are lower by a factor 100 than those found in surveys carried out in the UK (Woodhead 1983; Rogers et 
Table 3. Concentration of biocides in sewage sludge of WWTPs of different monitoring sites $(\mu \mathrm{g} / \mathrm{kg} \mathrm{d.w.)}$

\begin{tabular}{lllllllllll}
\hline Sites & Date & DSS & DM & Car & Ir & $\begin{array}{l}\text { Cis- } \\
\text { Per }\end{array}$ & $\begin{array}{l}\text { Trans- } \\
\text { Per }\end{array}$ & $\begin{array}{l}\text { Cis/ } \\
\text { trans }\end{array}$ & TBT & TPT \\
\hline A11 & 23 Jan & 110 & 4.3 & 1.7 & nd & 16.8 & 10.0 & 1.7 & 125.0 & 282.6 \\
& 09 May 230 & 2.5 & 1.6 & nd & 39.1 & 22.6 & 1.7 & 22.9 & 17.6 \\
A12 & 11 Jan 70 & 1.7 & 2.9 & nd & 59.5 & 36.7 & 1.6 & 180.4 & nd \\
& 07 May 190 & 1.4 & 9.2 & nd & 71.3 & 37.2 & 1.9 & 172.2 & nd \\
A15 & 16 Jan 120 & 2.8 & 2.2 & nd & 50.3 & 12.6 & 4.0 & 115.9 & 12.8 \\
& 07 May 230 & 2.3 & 1.9 & nd & 34.2 & 27.7 & 1.5 & 23.6 & nd \\
A16 & 16 Jan 120 & 4.0 & 2.1 & nd & 7.2 & 2.9 & 2.5 & 193.0 & nd \\
& 07 May 230 & 3.4 & 4.9 & nd & 13.5 & 23.9 & 0.6 & 43.8 & nd \\
B11 & 11 Jan 40 & 6.9 & 8.1 & nd & 80.1 & 102.5 & 0.8 & 505.1 & 33.0 \\
& 07 May 60 & 7.2 & 5.2 & nd & 74.6 & 81.4 & 0.9 & 82.8 & 4.3 \\
B14 & 16 Jan nd & 6.6 & 9.2 & nd & 127.0 & 88.6 & 1.4 & 137.9 & 39.6 \\
& 09 May 60 & 7.6 & 2.1 & nd & 133.6 & $78.9 *$ & 1.7 & 18.6 & 12.2 \\
B16 & 21/02 & 60 & 3.0 & 21.1 & 20.1 & 64.8 & 88.1 & 0.7 & 38.5 & nd \\
& 08 May 30 & 4.5 & 5.0 & nd & 36.0 & 26.8 & 1.3 & 24.2 & nd \\
B25 & 17 Jan 90 & 6.5 & 21.3 & 30.4 & 55.6 & 30.3 & 1.8 & 648.5 & nd \\
& 08 May 190 & 5.6 & 11.3 & 3.3 & 82.7 & 65.6 & 1.3 & 137.0 & 9.6 \\
C2 & 16 Jan 60 & 6.6 & 4.3 & nd & 38.2 & 45.0 & 0.8 & 323.8 & 35.1 \\
& 09 May 120 & 5.4 & 2.9 & nd & 20.5 & 33.2 & 0.6 & 46.2 & nd \\
C4 & 17 Jan 90 & 5.1 & 5.7 & 1.5 & 22.3 & 14.3 & 1.6 & 165.8 & 33.4 \\
& 08 May 190 & 5.5 & 5.8 & nd & 53.7 & 37.3 & 1.4 & 102.6 & 5.4 \\
C5 & 17 Jan 100 & 8.0 & 5.4 & 1.6 & 27.4 & 23.4 & 1.2 & 125.8 & nd \\
& 08 May nd & 6.3 & 5.8 & nd & 44.9 & 43.4 & 1.0 & 30.9 & nd \\
C9 & 17 Jan 30 & 3.7 & 3.7 & 7.2 & 62.7 & 34.5 & 1.8 & 166.2 & nd \\
& 08 May 30 & 3.1 & 20.1 & 5.9 & 110.3 & 64.8 & 1.7 & 117.3 & nd \\
\hline Mean & & & 6.8 & 2.9 & 55.3 & 42.8 & 1.5 & 147.8 & 20.2 \\
Median & & & 5.1 & 0.0 & 52.0 & 35.6 & 1.5 & 121.2 & 0.0 \\
Minimum & & & 1.6 & nd & 7.2 & 2.9 & 0.6 & 18.6 & nd \\
Maximum & & & 21.3 & 30.4 & 133.6 & 102.5 & 4.0 & 648.5 & 282.6 \\
\hline
\end{tabular}

nd : not detected (equal to zero for the calculation of the mean and the median) DSS: duration of sludge stocking (days), DM: dry matter (\%)

*confirmation of the concentrations by GC/MS

al. 1989). This difference can be explained by the release from point sources like textile industries, which are not present in the sites of the present study, by a different permethrin usage of the two countries or by a decreasing consumption in recent years. Additionally, the technology used for wastewater treatment might play a significant role for degradation of permethrin.

Among all compounds studied here, the highest concentrations were found for TBT (mean of $147.8 \mu \mathrm{g} \mathrm{TBT} / \mathrm{kg}$ d.w.). TPT was detected in 11 samples at contents below $40 \mu \mathrm{g} \mathrm{TPT}{ }^{+} / \mathrm{kg}$ d.w. except for one sample from site A11 $\left(282.6 \mu \mathrm{g} \mathrm{TPT} /{ }^{+} / \mathrm{kg}\right.$ d.w.). As the use of TPT acetate is authorized in Switzerland, its presence in sewage sludge could be explained by agricultural applications: surface runoff from treated soils and spray drift during applications of fungicides with subsequent dry or wet deposition on impervious surfaces, followed by washoff into sewer systems during rain events. The high concentration of TPT in sewage sludge of site A11, which has a separate system and is located in a rural area, could be explained by cleaning of agricultural equipment (i.e. measuring utilities) or improper disposal of a product 
containing TPT. It seems to be time limited, as the sample collected in May has shown lower concentrations of TPT than the January sample. A survey in 1995 in $25 \mathrm{WWTP}$ showed higher concentrations with an average of $1100 \mu \mathrm{g} \mathrm{TBT} / \mathrm{kg} \mathrm{d}$.w. and $500 \mu \mathrm{g} \mathrm{TPT} / \mathrm{kg}$ d.w. (Fent 1996b). Nevertheless, compared to the concentrations measured by Becker van Slooten et al. (1994), the TBT and TPT amounts are in the same range with contents of approximately $200 \mu \mathrm{g} \mathrm{TBT} / \mathrm{kg} \mathrm{d}$.w. and a maximum of $2150 \mu \mathrm{g} / \mathrm{kg} \mathrm{d.w}$. and TPT detected in 9 out of 54 samples with a maximum of $3400 \mu \mathrm{g} / \mathrm{kg} \mathrm{d}$.w. The highest concentrations of TBT and TPT observed in the present study are lower by a factor 3 and 12 respectively compared to the highest concentrations of TBT and TPT found by Becker van Slooten et al. (1994). This might indicate a decrease in consumption. In a more recent survey (Bancon-Montigny et al. 1999) TBT was found in concentrations at the same level (71-225 $\mu \mathrm{g} \mathrm{TBT}^{+} / \mathrm{kg}$ d.w.).

It cannot be excluded that wastewater and sludge treatment influence degradation of biocides. In order to determine if hygienisation of sludge enhances degradation of TBT, permethrin and carbendazim, the mean concentrations of disinfected (WWTPs B25, C2, C4, C5) and not disinfected sludge (WWTPs B11, B14, C9) were compared with a directional Wilcoxon-Mann-Whitney test. Both groups of WWTPs include an activated sludge process and are thus comparable with regard to wastewater treatment. Concentrations for permethrin in disinfected sludge (mean of $159.5 \mu \mathrm{g} / \mathrm{kg} \mathrm{d.w.)} \mathrm{were} \mathrm{significantly} \mathrm{lower} \mathrm{than} \mathrm{concentrations} \mathrm{in} \mathrm{not-disinfected}$ sludge $(346.3 \mu \mathrm{g} / \mathrm{kg}$ d.w.) at the $95 \%$ level of significance $(\mathrm{U}=0, \alpha=0,014)$. This indicates that hygienisation might enhance the degradation process of permethrin. However, the difference was not significant for the other compounds.

Concentrations of compounds in sewage sludge do not provide enough information to fully understand their release into wastewater. For instance, high loads of organic matter in wastewater induce a high sludge production which results in dilution of the concentrations of the studied compounds. Specific loads in sewage sludge per inhabitant connected to the WWTP per year account for this effect. The method has been described by Kupper et al. (2004). Figure 1 gives specific loads calculated for carbendazim, permethrin and TBT. The statistical significance of differences between the specific loads of sites A, B and C was determined by a directional Wilcoxon-Mann-Whitney test (Table 4).

Table 4. $U$ and significance level $(\alpha)$ of the non-parametric WilcoxonMann-Whitney test

\begin{tabular}{lcccccc}
\cline { 2 - 7 } & \multicolumn{2}{c}{$\mathrm{B}>\mathrm{A}$} & \multicolumn{2}{c}{$\mathrm{C}>\mathrm{A}$} & \multicolumn{2}{c}{$\mathrm{C}>\mathrm{B}$} \\
& $\mathrm{U}$ & $\alpha$ & $\mathrm{U}$ & $\alpha$ & $\mathrm{U}$ & $\alpha$ \\
\hline Carbendazim & 0 & $0.014^{*}$ & 0 & $0.014^{*}$ & 7 & 0.443 \\
Permethrin & 1 & $0.029^{*}$ & 1 & $0.029^{*}$ & 8 & 0.557 \\
TBT & 7 & 0.443 & 0 & $0.014^{*}$ & 6 & 0.343 \\
\hline
\end{tabular}

* significantly superior at $\alpha=0.05$

The presence of biocides in sludge of domestic origin (sites A) are probably the result of preservative's leaching during cleaning and washing of treated wood, textile, paper or surfaces. Biocides might also disperse into wastewater due to improper 


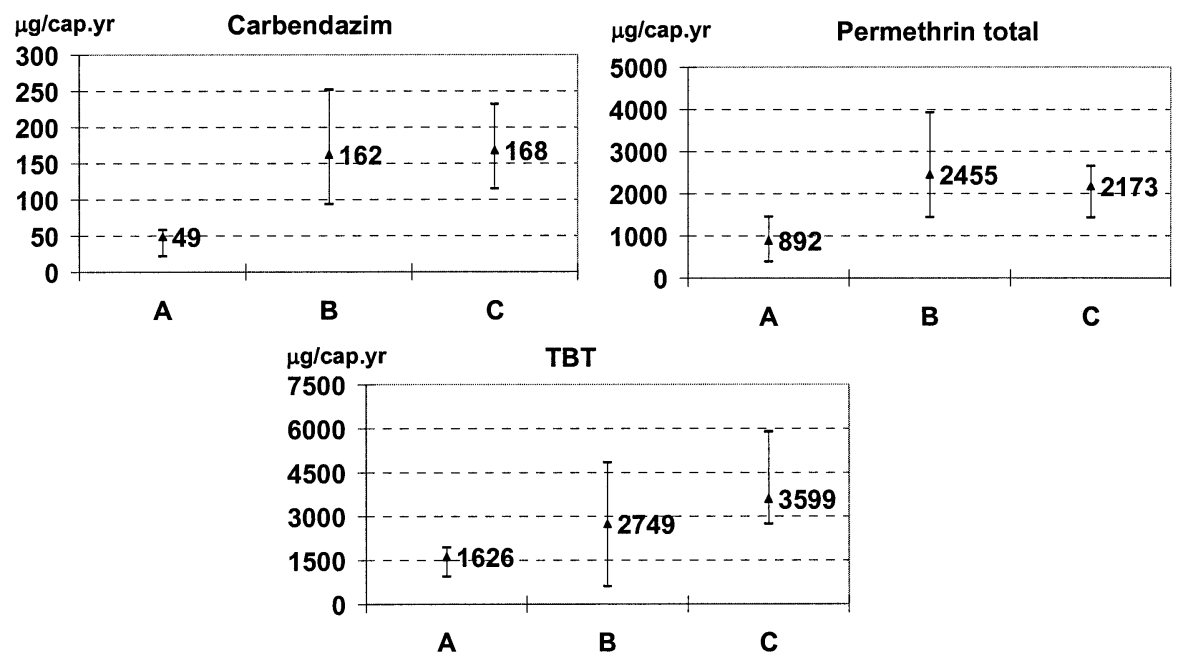

Figure 1. Minimum, mean and maximum of specific loads $(\mu \mathrm{g} /$ connected inhabitant (cap.).year) on different types of monitoring sites.

disposal of biocidal products. A possible source of TBT may be leaching from PVC products and dispersion paints (Fent 1996a). The considerable loads of permethrin might be due to its use in veterinary products against fleas or in insecticides for private housholds.

Except for TBT, specific loads for sites of type B are significantly higher than loads from sites of type A $(\alpha=0.05)$. It seems likely that surface runoff contributes to the load in sewage sludge. This could be explained by leaching during rain events of substances used for purposes such as wood protector and preservative in outdoor paints, or spraying drifts on impervious surfaces and the use in private gardens of products containing carbendazim, permethrin or benomyl, a substance quickly converted to carbendazim. Evaporation of biocides after use may cause ubiquitous distribution in the environment. According to Tomlin (1997), carbendazim and permethrin exhibit low vapour pressure $\left(<0.1 \mathrm{mPa}\right.$ at $\left.20^{\circ} \mathrm{C}\right)$. They are thus expected to occur in the particulate phase of the atmosphere. The contamination of sewage sludge might thus the consequence of dry or wet deposition and runoff from impervious surfaces into the sewer systems.

Differences between loads of sites $\mathrm{B}$ and $\mathrm{C}$ were not significant for the three biocides. It can be concluded that industrial activities don't induce additional loads. As mentioned earlier, hygienisation, which is present on most WWTPs of sites of type $\mathrm{C}$, might enhance degradation of permethrin, potentially masking a release of this compound by the industry. Further investigations are required to assess the role of industrial activities for the release of permethrin. For TBT, there is a significant difference between specific loads of sites of type A and sites of type $C$, but not between sites of type A and B. Thus, it seems that industrial wastewater is a potential source. As no data on the consumption of biocides in Switzerland are available, we are unable to compare the total loads found in this study with the amounts used. The comparison with other countries is also difficult because of a lack of data and the 
differences in terms of legislation and uses of the compounds on the market.

Acknowledgments. This work was funded by the Swiss Agency for the Environment, Forest and Landscape and a pool of swiss cantons (VD, FR, BE, LU, BL, AG and $\mathrm{ZH})$.

\section{REFERENCES}

Bancon-Montigny C, Lespes G, Potin-Gautier M (1999) Optimisation using experimental designs of the sample pretreatment: application to the control of the organotins in sewage sludge by GC-FPD. Analyst 124: 1265-1270

Becker van Slooten K, Merlini L, Stegmueller AM, de Alencastro LF, Tarradellas J (1994) Contamination des boues de stations d'épuration suisses par les organoétains. Gas-Wasser-Abwasser 2: 104-110

Chassot GM (1995) Recensement et évaluation du métabolisme anthropique sur la base des boues d'épuration. Département Génie rural et Mensurations, Ecole Polytechnique Fédérale de Zurich, Zurich

Fent K (1996a) Ecotoxicology of organotin compounds. Crit Rev Toxicol 26: 3-117

Fent K (1996b) Organotin compounds in municipal wastewater and sewage sludge: contamination, fate in treatment process and ecotoxicological consequences. Sci Total Environ 185: 151-159

Hancock PM, Yasin M, Baugh PJ, Bonwick GA, Davies DH (1997) Optimization of high quality analytical methods for the monitoring of pyrethroid moth proofing agents by gas chromatography mass spectrometry operated in negative-Ion chemical ionization mode. Int J Environ Anal Chem 67: 81-95

Hess P, de Boer J, Cofino WP, Leonards PEG, Wells DE (1995) Critical review of the analysis of non- and mono-ortho-chlorobiphenyls. J Chromatogr A 703: 417-465

Kupper T, Berset JD, Etter-Holzer R, Furrer R, Tarradellas J (2004) Concentrations and specific loads of polycyclic musks in sewage sludge originating from a monitoring network in switzerland. Chemosphere 54: 1111-1120

Lassen C, Skarup S, Mikkelsen SH, Kjoholt J, Nielsen PJ, Samsoe-Petersen L (2001) Inventory of biocides used in Denmark. Environmental Project No. 585.

Oeberg K, Warmann K, Oeberg T (2002) Distribution and Levels of Brominated Flame Retardants in Sewage Sludge. Chemosphere 48: 805-809

Rogers HR, Campbell JA, Crathorne B, Dobbs AJ (1989) The occurence of chlorobenzenes and permethrins in twelve U.K. sewage sludges. Water Res 23: 913-921

Sharom MS, Solomon KR (1981) Adsorption-desorption, degradation and distribution of permethrin in aqueous systems. J Agric Food Chem 29: 11221125

Tomlin CDS (1997) The Pesticide Manual: A World Compendium. 11 th ed, British Crop Protection Council, Surrey

Wegener JWM, Maier EA, Kramer GN, Cofino WP (1997) The certification of the contents (mass fractions) of chlorobiphenyls IUPAC No 28, 52, 101, 105, 118 , $128,138,149,153,156,163,170$ and 180 in freshwater harbour sediment CRM 536. European Commision, bcr information reference materials

Woodhead D (1983) Permethrin trials in the Meltham Sewage Catchment-Area. Water Ser 87: 198-202 